\title{
THE LAW OF NATIONS AS PART OF THE NATIONAL LAW OF THE UNITED STATES, II.
}

Edwin Dewitt Dickinson $\dagger$

I.

In an earlier paper published under the same title, ${ }^{1}$ and to which this paper is a sequel, the reader was reminded that the idea of individual offences against the Law of Nations was firmly established in countries of the common law in the eighteenth century. Piracies and violations of ambassadorial privilege were the stock examples. Blackstone observed characteristically that while offences against the Law of Nations were "principally incident to whole states or nations . . . where the individuals of any state violate this general law, it is then the interest as well as duty of the government under which they live, to animadvert upon them with a becoming severity, that the peace of the world may be maintained." 2 Animadversions by act of parliament were "not to be considered as introductive of any new rule, but merely as declaratory of the old fundamental constitutions of the kingdom; without which it must cease to be a part of the civilized world." 3

In America the opinion that such offences should be matters of national responsibility and power ran a course in the Constitutional Convention which may be identified with no great difficulty in the records of debates and other contemporary sources. The examples given were generally from Blackstone and even turns of phrase appear now and again to have been suggested by the same authority. It is enough for present purposes to refer once more to Randolph's enumeration of the defects of confederation, to debates on the Virginia Plan which Randolph presented, to the Pinckney Plan, and to the New Jersey Plan and Madison's initial comments upon its adequacy. ${ }^{4}$ In the outcome, the Constitution vested the national legislature with power "to define and punish piracies and felonies committed on the high seas, and

$\dagger$ Professor of Law, University of Pennsylvania Law School; Member on the part of the United States of the Permanent Court of Arbitration; sometime President of the American Society of International Law; author of books and articles on International Law and related subjects.

1. 101 U. of PA. L. Rev. 26 (1952).

2. $4 \mathrm{BL}$. CoMm. 68 (1st ed. 1765-1769).

3. $4 \mathrm{id}$, at 67 .

4. Dickinson, supra note 1 , at $36-38$. 
offenses against the law of nations." Madison thought that "the definition of piracies might perhaps, without inconveniency, be left to the law of nations," though he noted that a legislative definition was found in most municipal codes. ${ }^{5}$ In the outcome, also, the judicial power was extended to "all cases of admiralty and maritime jurisdiction" (italics added) and to "all cases affecting ambassadors, other public ministers and consuls" (italics added), formulations broad enough certainly to include both criminal and civil matters. That the first Judiciary Act was intended to give the district and circuit courts of the United States a jurisdiction of crimes at common law and under the Law of Nations as part of the common law is supported in the strongest terms by what we know now of the Act's legislative history. ${ }^{6}$ Had the jurisdiction been exercised initially in cases of piracy or ambassadorial privilege, it may be confidently surmised that there would have been no significant opposition on the part of either lay or professional critics. As history would have it, however, the initial exercise fell in the more debatable and the much more explosive area of offences against neutrality. In consequence the basic questions of constitutional power and statutory purpose were soon lost to view in the gathering clouds of political controversy.

France was again at war with Britain and Britain's continental allies. The political parties which were beginning to form in America were violently partisan about everything that pertained to France. Washington's Proclamation of April 22, 1793, brought the matter to an issue by warning, among other things, that United States authorities had been instructed to prosecute all persons "who shall, within the cognizance of the courts of the United States, violate the law of nations, with respect to the powers at war, or any of them." 7 Chief Justice Jay's famous charge to the grand jury at Richmond a month later described the laws of the United States as including, in addition to the Constitution and statutes of the United States, the Law of Nations and all treaties made under authority of the United States. The proclamation of neutrality, said the Chief Justice, "is exactly consistent with and declaratory of the conduct enjoined by the law of nations." 8 At Philadelphia in July, Justice Wilson delivered a charge elaborating further upon the same theme, with many references to Blackstone and Vattel; and at Philadelphia one Gideon Henfield was indicted and tried before a special circuit court of the United States for enlisting on a

5. The Federaltst, No. 42.

6. Warren, Neze Light on the History of the Federal Judiciary Act of 1789, 37 HaRv. L. REV. 49, 51, 73 (1923).

7. Axr. State Papers I, 45.

8. Wharton, State Trials, 49, 52, 54 (1849). 
French privateer. 9 The evidence appears to have been but slightly disputed and the court's denunciation of the acts committed as offences against the Law of Nations and treaties was comprehensive and emphatic. The jury acquitted notwithstanding. Though similar indictments were returned from time to time thereafter, their basic theory encountered an increasing popular disfavor. The national jurisdiction of crimes at common law and under the Law of Nations had become the subject of a bitter partisan contention between the Federalist and the Jeffersonian parties.

When the question of a national common law of crimes ultimately reached the Supreme Court of the United States in 1812, in a case certified from the Circuit Court for the District of Connecticut, partisanship had so completely beclouded the issue that neither the Attorney General of the United States nor counsel for defendants was willing to argue. The question was: "whether the Circuit Court of the United States had a common law jurisdiction in cases of libel." This question the Court, without benefit of argument, answered in the negative. Speaking for the majority in a brief, loosely reasoned and completely unfortified opinion, Justice Johnson said:

"The only question which this case presents is, whether the circuit courts of the United States can exercise common-law jurisdiction in criminal cases. We state it thus broadly, because a decision in a case of libel will apply to every case in which jurisdiction is not vested in those courts by statute.

Although this question is brought up now, for the first time, to be decided by this court, we consider it as having been long since settled in public opinion." 10

This somewhat extraordinary process of constitutional development by default came to full fruition four years later when the same broad question was certified from the District of Massachusetts. The case was an indictment for forcibly rescuing a prize from American privateers on the high seas. ${ }^{11}$ The question was: "whether the Circuit Court has jurisdiction over common law offences against the United States?" The Supreme Court was disposed to hear the question argued, but again the Attorney General of the United States declined. The whole opinion, again by Justice Johnson, was as follows:

9. Id. at 49, 59, 66, 77. See 1 Warren, Supreme Court in United States HISTORY, 112-115 (1932).

10. United States v. Hudson and Goodwin, 7 Cranch 32 (U.S. 1812).

11. Justice Story had delivered an opinion in the court below in which he supported vigorously the conclusion "that all offences within the admiralty jurisdiction are cognizable by the Circuit Court, and in the absence of positive [statutory] law, are punishable by fine and imprisonment." United States v. Coolidge, 1 Gallis. 488, 497, 25 Fed. Cas. 622, 623, No. 14,858 (C.C.D. Mass. 1815). 
"Upon the question now before the court a difference of opinion has existed, and still exists, among the members of the Court. We should, therefore, have been willing to have heard the question discussed, upon solemn argument. But the attorney-general has declined to argue the cause; and no counsel appears for the defendant. Under these circumstances, the court would not choose to review their former decision in the case of the United States v. Hudson and Goodwin, or draw it into doubt. They will, therefore, certify an opinion to the circuit court in conformity with that decision." 12

Thus the premise that individuals might offend against the Law of Nations and become punishable in the federal courts in the administration of a federal common law of crimes, so recently affirmed by framers of the Constitution and implemented by the draftsmen of the first Judiciary Act, came to be somewhat unceremoniously abandoned. Thus the way was prepared for the sequence of repetitious assertions in which it was to become established that crime against the United States is wholly statutory.

Something was saved, oddly enough, which is relevant to our present inquiry. There must be federal legislation before there can be federal crime; but in at least one area of international concern and perhaps in others it is sufficient if the legislation defines by reference to the Law of Nations. An Act of 1819 made piracy "as defined by the law of nations" punishable with death. ${ }^{13}$ The Act was challenged almost immediately as an insufficient exercise of the power to define. The Supreme Court held otherwise. Speaking for the Court, Justice Story took account of piracy in the Law of Nations and in the maritime and common law and concluded: "We have, therefore, no hesitation in declaring, that piracy, by the law of nations, is robbery upon the sea, and that it is sufficiently and constitutionally defined by the fifth section of the act of 1819." 14

II.

While the national jurisdiction at common law of offences against the Law of Nations was thus virtually to die a-borning, in political controversies to arise soon after the national Constitution was adopted, the reception of eighteenth century premises with respect to the law

12. United States v. Coolidge, 1 Wheat. $415,416-417$ (U.S. 1816).

13. Act of March 3, 1819, c. 77, \$5, 3 STAT. 510, 513; now, with the penalty reduced to imprisonment for life, 62 STAT. 774 (1948), 18 U.S.C. \$1651 (Supp. 1952). See Dickinson, Is the Crime of Piracy Obsolete, 38 HARv. L. REv. 334, 342-350 (1925). Cf. Act of April 30,1790, c. 9, \$28, 1 SтAт. 112, 118; now, somewhat revised, in 18 U.S.C. $\$ \$ 112,1545$.

14. United States v. Smith, 5 Wheat. 153, 162 (U.S. 1820). 
of merchants was to lay the ground for a judicial controversy which still projects its lights and shadows and which, in important respects, has been vastly more confused.

It will be recalled that the law of merchants constituted a branch of the Law of Nations, as understood by English and American lawyers of the eighteenth century, and that as such it was assumed to have been substantially incorporated into the common law. ${ }^{15}$ Although the records of debates in the Constitutional Convention are singularly barren of express references to the law of merchants, there are indications enough that it was never entirely out of mind. It will be recalled that the resolutions in which the Virginia Plan was first presented proposed that the jurisdiction of inferior federal tribunals include, along with other matters of international concern, "cases in which foreigners or citizens of other States applying to such jurisdiction may be interested," that the Pinckney Plan contemplated a provision for appeals from state courts to a supreme national tribunal in all causes wherein questions shall arise "on the Law of Nations," and that even the New Jersey Plan would have provided for appeals from state courts to a supreme tribunal "in all cases in which foreigners may be interested." 18 It will be recalled further that these ideas found precise and comprehensive expression in provisions of the Constitution defining the national judicial power and that the constitutional provisions were the subject of illuminating comment in several numbers of The Federalist, notably in numbers contributed by Hamilton and Jay. Of the provisions for judicial power, those based upon so-called diversity of citizenship or allegiance were implemented in the Judiciary Act of 1789 with respect to both the jurisdiction of causes and the applicable law and in each revision or codification thereafter. From the sources examined up to this point it is clear enough, we think, that the implementing had two objectives: first, an assurance that citizens of other states or foreigners need suffer nothing from local prejudice or passion; and second, an assurance of uniform judicial interpretation and application of laws with respect to matters of a paramount national concern. That matters traditionally resolved by reference to the law of merchants as part of the common law were matters of a paramount national concern seems not to have been questioned in

15. 1 Br. CoMm. 75, 263-264 (1765); 1 WILsow, Works, 374-375 (Bird Wilson ed. 1804) ; Dickinson, supra note 1, at 27; Steinmetz v. Currie, 1 Dall. 269 (U.S. 1788). See Sanborn, Origins of the Early English Maritime and Commercial Law, $3-41,125-261,324-401$ (1930).

16. Dickinson, supra note 1 , at 36-38. It is of more than passing interest that, at some stage in the Committee of Detail's consideration of the New Jersey Plan, Wilson suggested a further detailing of the proposed appellate jurisdiction to include all cases arising "on the Law of Nations, or general commercial or marine Laws." 2 RECORDS of THE FEDERAL Convention of 1787, 157 (Farrand ed. 1911). 
the earlier or formative years of our national life. Indeed, there is little or nothing in the reported decisions of the earlier years to suggest that the question was agitated.

Then came Swift $v$. Tyson in 1842.17 A bill of exchange dated in Maine had been accepted by Tyson in New York and endorsed to Swift in Maine in payment of an antecedent debt. Swift, citizen of Maine, sued Tyson, citizen of New York, in a federal court in New York; and Tyson defended that he had been imposed upon by the drawer's fraud and that under New York decisions Swift, having taken in payment of an antecedent debt, could not be regarded as a bona fide holder for value. On a certificate of division from the lower court, the question before the Supreme Court was whether evidence of the drawer's fraud was admissible against Swift. More broadly stated, the question was whether the issue as to Swift's position as endorsee in payment of an antecedent debt was to be resolved under national commercial law whatever the true import of local New York decisions might be. The arguments of counsel ranged widely and included some extreme contentions. Counsel for plaintiff relied upon national commercial law and advanced the contention, among others, that the phrase "laws of the several states" in Section 34 of the Judiciary Act of 1789 referred only to "the written constitutional system and statutes of such states." 18 This proposition was of course a good deal more than plaintiff needed to prove. Counsel for defendant denied the existence of a national common law in commercial matters and for this contention relied, oddly enough, upon the cases which already had denied the existence of a national common law of crimes. ${ }^{19}$ This was a straining of dubious analogy, to say the least. The Supreme Court was unanimous in answering the question certified in the negative. Whatever the local case law might be-and on this matter it was assumed that there might be doubt-the question was one to be resolved under "general commercial law." Under this law, said Justice Story for the Court, "we have no hesitation in saying, that a preexisting debt does constitute a valuable consideration . . . as applicable to negotiable instruments." 20

This was what the Court decided and all that it decided. ${ }^{21}$ It would have been enough to add that cases arising under the law of merchants or "general commercial law" were not cases in which "the

17. 16 Pet. 1 (U.S. 1842).

18. Id. at $3,5,8$.

19. Id. at 9,11 .

20. Id. at 19 .

21. Justice Story said: "the only real question in the cause is, whether, under the circumstances of the present case, such a pre-existing debt constitutes a valuable consideration, in the sense of the general rule applicable to negotiable instruments." Id. at 16. 
laws of the several states" were intended to apply, as constitutional and legislative history would amply demonstrate. Unhappily, Justice Story was persuaded to respond to the arguments of counsel in a confusion of comment upon history which was luminous, so far as it went, and of comment upon the meaning of Section 34 which was anything but illuminating. In anticipation of the confusion to follow, his opinion at this point must be quoted at some length. Commenting upon the meaning of Section 34, he said:

"In the ordinary use of language, it will hardly be contended, that the decisions of courts constitute laws. They are, at most, only evidence of what the laws are, and are not, of themselves, laws. ... The laws of a state are more usually understood to mean the rules and enactments promulgated by the legislative authority thereof, or long-established local customs having the force of laws. In all the various cases, which have hitherto come before us for decision, this court have uniformly supposed, that the true interpretation of the 34 th section limited its application to state laws, strictly local, that is to say, to the positive statutes of the state, and the construction thereof adopted by the local tribunals, and to rights and titles to things having a permanent locality, such as the rights and titles to real estate, and other matters immovable and intra territorial in their nature and character. It never has been supposed by us, that the section did apply, or was designed to apply, to questions of a more general nature, not at all dependent upon local statutes or local usages of a fixed and permanent operation, as, for example, to the construction of ordinary contracts or other written instruments, and especially to questions of general commercial law, where the state tribunals are called upon to perform the like functions as ourselves, that is, to ascertain, upon general reasoning and legal analogies, what is the true exposition of the contract or instrument, or what is the just rule furnished by the principles of commercial law to govern the case. And we have not now the slightest difficulty in holding, that this section, upon its true intendment and construction, is strictly limited to local statutes and local usages of the character before stated, and does not extend to contracts and other instruments of a commercial nature, the true interpretation and effect whereof are to be sought, not in the decisions of the local tribunals, but in the general principles and doctrines of commercial jurisprudence. . . . The law respecting negotiable instruments may be truly declared in the language of Cicero, adopted by Lord Mansfield in Luke v. Lyde, 2 Burr. 883,887 , to be in a great measure, not the law of a single country only, but of the commercial world. Non erit alia lex Rome, alia Athenis, alia nunc, alia posthac; sed et apud omnes gentes, et omni tempore, una eademque lex obtenebit." 22

22. Id. at 18-19. Justice Story was here taking his Cicero from Mansfield, who probably quoted from memory. Cf. Justice Story's quotation of the same lines from the original ( $D e$ Republica, Lib. III, xxii) in his earlier and abler admiralty opinion in De Lovio v. Boit, infra at note 47. 
With so confused an exegesis to guide, the courts were bound to have difficulty in finding their way through the maze of questions certain to arise in a nation organized on federal principles. Difficulty began almost immediately. At the same term, the Supreme Court ruled in an opinion by Justice Story that the construction of a policy of fire insurance on a New York factory presented "questions of general commercial law." 23 The point may have been arguable, but there was more and worse to come. The country was becoming increasingly absorbed in westward expansion and internal development. The law of merchants for most lawyers was fast slipping into the limbo of forgotten history. The clash of words over national versus state power was moving steadily toward the ultimate clash of arms. In such a climate, the Supreme Court was to cultivate, stoutly maintain and even expand an utterly untenable position with respect to the law applicable in the federal courts in diversity cases. It soon ceased to be a question of conserving intended national law in matters of international concern, as in the controversy over a national common law with respect to crimes; rather it became a question of conserving the common law of the several states in areas where no paramount national law had ever been intended.

Before the Civil War, the Supreme Court had indicated that it would accord "respect" but not controlling effect to applicable local decisions concerning the construction of a clause in the will of a Mississippi testator devising Mississippi land, ${ }^{24}$ the construction of a reservation or condition in a deed of land in Maine, ${ }^{25}$ and the question of an owner's responsibility for the negligence of his independent contractor in excavating premises abutting on a Chicago street. ${ }^{26}$ Already, within two decades, the Court's formula descriptive of the federal law, assumed to be controlling in the federal courts in diversity cases, had metamorphosed from "general commercial law" into "general law" into "common law." After the Civil War and before the century ran out, the same Court was to become similarly committed with respect to a question of dedication to public use of land suitable for a wharf site on or under a navigable river, ${ }^{27}$ a question as to the validity of a statutory authorization of local taxation in aid of railroad construc$1842)$.

23. Carpenter v. Provident Washington Insurance Co., 16 Pet. 495, 511 (U.S.

24. Lane v. Vick, 3 How. 464, 476 (U.S. 1845). Justice McKinley filed a vigorous dissenting opinion in which Chief Justice Taney concurred.

25. Foxcroft v. Mallett, 4 How. 353, 379 (U.S. 1846).

26. Chicago City v. Robbins, 2 Black 418, 428 (U.S. 1862).

27. Yates v. Milwaukee, 10 Wall. 497, 506 (U.S. 1870). 
tion, ${ }^{28}$ a question as to the validity of a railroad's stipulation against liability for negligent injury to one travelling on a drover's pass, ${ }^{29}$ a question as to the applicability of the fellow-servant doctrine as between a railroad fireman and his engineer, ${ }^{30}$ and other matters of a comparable local concern.

The particular cases to which reference is here made, by way of illustration, are those which a majority of the Supreme Court were to note as their principal reliance a generation later in deciding Black and White Taxicab Co. v. Brown and Yellow Taxicab Co. ${ }^{31}$ Two Kentucky taxicab companies were in controversy concerning access to the premises of a Kentucky railroad company to solicit patronage. Contracts for exclusive access were invalid under the Kentucky decisions. Accordingly, the complaining company reincorporated in Tennessee, procured from the railroad an exclusive contract, and then invoked the diversity jurisdiction of the local federal court to enjoin its rival from interfering. The injunction was granted and the Supreme Court affirmed. In the view of the majority, it was a question of general common law. Justices Holmes, Brandeis and Stone dissented. The prevailing doctrine had been accepted upon a fallacy never analyzed, said Justice Holmes, and the fallacy had resulted in "an unconstitutional assumption of power by the Courts of the United States which no lapse of time or respectable array of opinion should make us hesitate to correct." "I should leave Swift v. Tyson undisturbed," Justice Holmes concluded, "but I would not allow it to spread the assumed dominion into new fields." 32

Spread of the assumed dominion, initiated originally in reliance upon Justice Story's extraordinary digression in Swift $v$. Tyson, had now reached a stage at which reconsideration was rather obviously overdue. As such matters move in our supreme tribunal, reconsideration came promptly. In Erie Railroad Co. v. Tompkins, a suit brought in a federal court in New York to recover for personal injuries suffered in Pennsylvania, the case turned upon the measure of a railroad's lia-

28. Olcott v. The Supervisors, 16 Wall. $678,689-690$ (U.S. 1872). Chief Justice Chase and Justices Miller and Davis dissented.

29. Railroad Company v. Lockwood, 17 Wall. 357, 367-368 (U.S. 1873). See also Liverpool and Great Western Steam Co. v. Phenix Insurance Co., 129 U.S. 397,443 (1889). This latter case turned on the validity of a stipulation against liability for cargo damage attributable to the master's negligence in an ocean bill of lading. It was a libel in personam in admiralty and the argument based upon judicial proliferations of Swift $v$. Tyson was of course completely irrelevant.

30. Baltimore and Ohio Railroad Co. v. Baugh, 149 U.S. 368,370 (1893). On this occasion Justice Field confessed his earlier errors and filed a long and devastating dissent.

31. 276 U.S. 518 (1928).

32. Id. at $532-533,535$. 
bility to a plaintiff who had been struck by something projecting from a passing freight train while he was walking along the railroad's right of way on a dark night. Was this a question to be resolved, in the exercise of diversity jurisdiction, under local or general law? The lower federal courts sustained a recovery in reliance upon general law. The Supreme Court reversed, two justices dissenting. ${ }^{33}$

"The question for decision," said Justice Brandeis for the majority, "is whether the oft-challenged doctrine of Swrift $v$. Tyson shall now be disapproved." Justice Brandeis made no distinction between what was actually decided in the case and what was said in discourse about the meaning of Section 34. He began the substantive part of his opinion by attributing to the case, not what it decided, but rather what its proliferations had come to mean in the intervening years. He said: "Swift v. Tyson, 16 Pet. 1, 18, held that federal courts exercising jurisdiction on the ground of diversity of citizenship need not, in matters of general jurisprudence, apply the unwritten law of the State as declared by its highest court; that they are free to exercise an independent judgment as to what the common law of the State is-or should be. ..." Doubts had been expressed repeatedly over the years and more recently it had been established that "the purpose of the section was merely to make certain that, in all matters except those in which some federal law is controlling, the federal courts exercising jurisdiction in diversity of citizenship cases would apply as their rules of decision the law of the State, unwritten as well as written." 34 The socalled "doctrine of Swift $v$. Tyson" had not produced uniformity of state decisions. On the contrary, it had developed "a new well of uncertainties" and had prevented "uniformity in the administration of the law of the State."

"In disapproving that doctrine we do not hold unconstitutional $\$ 34$ of the Federal Judiciary Act of 1789 or any other Act of Congress. We merely declare that in applying the doctrine this Court and the lower courts have invaded rights which in our opinion are reserved by the Constitution to the several States." 35

It would serve no present purpose to examine in detail the aftermath of Erie Railroad Co. $v$. Tompkins. There has been a spate of litigation and professional comment in corresponding volume. ${ }^{38}$ To

33. 304 U.S. 64 (1938).

34. Id. at $69,71,72$. Here the reference was to Warren, supra note 6 , at 51-52, $81-88,108$.

35. 304 U.S. 74-75, 79-80.

36. See Wolkin, Conflict of Lazes in the Federal Conts: Thirteen Years of Erie R.R. Co. v. Tompkins, 3 SyRacuse L. Rev. 47 (1951). 
date it has been the evident concern of the Supreme Court to assure that all matters outside the scope of a paramount national law or policy shall be resolved in substantially the same way whether prosecuted in a state court or in a federal court in the exercise of diversity jurisdiction. Even cases turning upon interstate conflict of laws, including cases in which the usual conflict of laws solution is barred by a strongly held local policy, have yielded to this concern. ${ }^{37}$ At the same time the Supreme Court has been obliged to remind a seemingly somewhat bewildered bar that where the Constitution contemplates a paramount national law or policy the laws of the several states are inapplicable and that it makes no difference whether the issue is presented in a diversity case or in a case arising under some other grant of national judicial power. On the same day that the Erie case was decided, the Court decided another case which had been taken up on certiorari to a state court and which presented a question of equitable apportionment pursuant to interstate compact of the waters of a stream flowing through two states. For the Court, Justice Brandeis said, "whether the water of an interstate stream must be apportioned between the two States is a question of 'federal common law' upon which neither the statutes nor the decisions of either State can be conclusive." 38 Four years later, again on certiorari to a state court, the Supreme Court resolved a conflict between state and national law with respect to a shipowner's burden of proof when relying upon a seaman's release in a suit for damages under the Jones Act and for maintenance and cure. Said Justice Black for the Court: "The source of the governing law applied is in the national, not the state, government." ${ }^{39}$

Some may have anticipated that there would be less difficulty where national legislation has occupied the field. It has not been so. In a number of cases arising under federal statutes the Supreme Court has found itself obliged to stress firmly a paramount national law or policy and to warn against becoming involved in the implications of Erie. ${ }^{40}$ A case of even more compelling interest, among other reasons because it involved no particular exercise of a national legislative power, is Clearfield Trust Co. v. United States. The case originated in a federal court and presented a question as to the delay which will

37. See Klaxon Co. v. Stentor Electric Manufacturing Co., 313 U.S. 487 (1941); Griffin v. McCoach, 313 U.S. 498 (1941).

110 (1938).

38. Hinderlider v. La Plata River \& Cherry Creek Ditch Co., 304 U.S. 92,

39. Garrett v. Moore-McCormack Co., 317 U.S. 239, 245 (1942).

40. See D'Oench, Duhme \& Co. v. Federal Deposit Insurance Corporation, 315 U.S. 447 (1942); Holmberg v. Ambrecht, 324 U.S. 392 (1946); Vanston Bondholders Protective Committee v. Green, 329 U.S. 156 (1946); Note, 30 ORE. L. REV. 164 (1951). 
bar reimbursement of the United States as drawee of a government check on which the payee's endorsement has been forged. For the Court, Justice Douglas said:

"We agree with the Circuit Court of Appeals that the rule of Erie R. Co. v. Tompkins, 304 U. S. 64, does not apply to this action. The rights and duties of the United States on commercial paper which it issues are governed by federal rather than local law. When the United States disburses its funds or pays its debts, it is exercising a constitutional function or power. . . . In absence of an applicable Act of Congress it is for the federal courts to fashion the governing rule of law according to their own standards. ...

The desirability of a uniform rule is plain. And while the federal law merchant, developed for about a century under the regime of Swift v. Tyson, 16 Pet. 1, represented general commercial law rather than a choice of a federal rule designed to protect a federal right, it nevertheless stands as a convenient source of reference for fashioning federal rules applicable to these federal questions." $\leqslant 1$

So the federal law merchant is still useful when it comes to the fashioning of a federal rule to protect a federal right; and one may think of other areas in which in all likelihood there is a persisting vitality. As general commercial law in the federal courts in diversity cases, however, it would appear to be quite dead. No case quite like Swift $v$. Tyson has reached the Supreme Court since Erie was decided; but when it does, if ever, it is to be anticipated that the rule of the earlier case will go the way of its more famous dictum. The law of merchants had vitality as universal law in the eighteenth century. The more learned of the lawyer-delegates to the Constitutional Convention anticipated for it a continuing and uniform progress in the United States as part of the national law. Assurance of such progress was one of the objectives of diversity jurisdiction. But diversities of state citizenship have long since ceased to be as meaningful as they once were. The need for uniformity in the commercial field has been largely met by the now familiar device of uniform state laws. In writing finis to the judicial overreaching which followed its earlier decision, it seems clear enough that the Supreme Court has written finis also to the eighteenth century premise upon which Swift $v$. Tyson was once securely based.

III.

The reception in America of eighteenth century premises with respect to the law maritime is another and a quite different story. 
There were a number of reasons why this branch of the Law of Nations would progress in the United States with emphasis upon its supremacy and uniformity as part of the national law. Of the entire body of law and practice considered international in the eighteenth century, the law maritime was at least as old if not older than any other; it was in important respects the most coherent; and in many respects it was the most comprehensive. ${ }^{42}$ With such departures as were attributable generally to local needs or conditions, it had come to be respected wherever seaborne trade was a prime concern. It had become established long since as a part of the law of England, where the wide range of its sources, the peculiar liberality of its procedures, the specialized competence required of its practitioners and the zealously guarded jurisdiction which its separate court had been able to retain in contests with the common law had combined to give it a unique identity. Englishmen adventuring in maritime commerce had taken it with them into English colonies overseas. In America, prior to the Revolution, there had been a considerable experience with the subject in admiralty or other courts in the seaport cities; and in America, when independence was achieved, maritime commerce was "the jugular vein of the Thirteen States." 43

Maritime causes, both criminal and civil, received a good deal of attention in the Constitutional Convention and the "need for a body of law applicable throughout the nation was recognized by every shade of opinion." The desirability of independent lower federal courts of admiralty "found general concurrence or, at least, did not encounter vigorous opposition even from the Anti-Federalists." ${ }^{44}$ In the Constitution as drafted and adopted, the whole range of maritime matters was covered adequately in provisions for the national legislative and judicial power. The judicial power was implemented immediately and in terms which made it exclusively national except as the Judiciary Act saved to suitors in civil causes "the right of a common law remedy where the common law is competent to give it." Obviously there would be difficult peripheral problems, with respect to both the jurisdiction of courts and the governing law, wherever land law meets the sea; but it is quite as obvious that the main course had been charted clearly.

42. See SANBoRN, op. cit. supra note 15. Sanborn says (at 19): "Indeed it cannot be too strongly emphasized that throughout classical antiquity, through the Dark and Middle Ages, and until comparatively recent times the greatest characteristic of maritime law has been that its uniform provisions were known and enforced in every seaport of every nation."

43. See Frankfurter and Landis, The Business of the Supreme Court, 7 (1927) and references there cited.

44. Id. at 7,8 . 
Within four years after the new government was inaugurated, in his individual opinion in the famous case of Chisholm v. Georgia, ${ }^{45}$ Chief Justice Jay found occasion to undertake a "cursory view of the judicial powers of the United States." These powers included "all cases of admiralty and maritime jurisdiction," said the Chief Justice, "because, as the seas are the joint property of nations, whose rights and privileges relative thereto, are regulated by the law of nations and treaties, such cases necessarily belong to national jurisdiction." Every lawyer knows of Chisholm v. Georgia and of its denouement in the Eleventh Amendment. ${ }^{40}$ Perhaps fewer know that the Chief Justice's dictum concerning admiralty epitomized a view which had prevailed in the Convention and which continued to accord with the more general understandings of bench and bar. The great contests which would arise as cases required the application of general understandings in particular situations would come later. In the period between the adoption of the Constitution and the Civil War, these contests would be concerned chiefly with the content and the areas of judicial jurisdiction in maritime matters.

Sitting on circuit in 1815, Justice Story was confronted with the question whether a policy of marine insurance was a maritime contract cognizable in admiralty. He undertook "a thorough examination of the whole jurisdiction of the admiralty," rejected the more restricted view which had come to prevail in England at the time the Constitution was adopted, and concluded that marine insurance was maritime. He said in summary:

"The language of the constitution will therefore warrant the most liberal interpretation; and it may not be unfit to hold, that it had reference to that maritime jurisdiction, which commercial convenience, public policy, and national rights, have contributed to establish, with slight local differences, over all Europe; that jurisdiction, which, under the name of consular courts, first established itself upon the shores of the Mediterranean, and, from the general equity and simplicity of its proceedings, soon commended itself to all the maritime states; that jurisdiction, in short, which, collecting the wisdom of the civil law, and combining it with the customs and usages of the sea, produced the venerable Consolato del Mare, and still continues in its decisions to regulate the commerce, the intercourse, and the warfare of mankind. . . . Of this great system of maritime law it may be truly said, 'Non erit alia lex Romae, alia Athenis, alia munc, alia posthac; sed et

45. 2 Dall. 419, 475 (U.S. 1793).

46. 1 WARREN, op. cit. supra note 9, 93-102. 
omnes gentes, et omni tempore, una lex, et sempiterna et immortalis, continebit." "47

A generation was to pass before a comparable issue would reach the Supreme Court in New Jersey Steam Navigation Company v. Merchants' Bank. In this case the principal question was whether a contract for the carriage of goods by sea was maritime and so within the grant of admiralty jurisdiction. Was the grant to be read with reference to the restricted authority of the English admiralty at the time the Constitution was adopted; or, as Justice Story had contended in De Lovio $v$. Boit, with reference to the more enlarged authority of maritime courts that had existed then and since in other maritime countries? History was explored and the question was argued and reargued at great length. A sharply divided Court sustained the more enlarged jurisdiction and held the affreightment contract maritime, a view which has since prevailed. The grant was intended to be comprehensive as well as exclusive. The federal court was "a maritime court instituted for the purpose of administering the law of the seas." 48

At its. previous term the Supreme Court had resolved another great admiralty case, quite as sharply contested as the one just reviewed, in which the waters within the admiralty power were at issue. It was a libel in rem in admiralty arising out of a collision on the Mississippi River nearly a hundred miles above New Orleans. If restrictive English precedents persisting throughout the eighteenth century had been followed, the Court would have been constrained to say that the collision had occurred infra corpus comitatus and so within the jurisdiction of the common law courts. However, in this case, reported as Waring $v$. Clarke, a majority of the Court concluded "that the grant of admiralty power to the courts of the United States was not intended to be limited or to be interpreted by what were cases of admiraly jurisdiction in England when the constitution was adopted." Rather it was to be interpreted in accordance with "the general admiralty law." Accordingly the admiralty jurisdiction was sustained. ${ }^{49}$

47. De Lovio v. Boit, 2 Gallis. 398, 472, 7 Fed. Cas. 418, 443, No. 3,776 (C.C.D. Mass. 1815). When the precise question was finally presented to the Supreme Court fifty-five years later, Justice Story's opinion was praised as "a monument of his great erudition" and his conclusion as to policies of marine insurance was approved as correct. Insurance Company v. Dunham, 11 Wall. 1, 35 (U.S. 1870).

48. 6 How. 344, 392 (U.S. 1848). Chief Justice Taney and Justices McLean and Wayne appear to have concurred with Justice Nelson in support of the more enlarged view. Justices Catron and Woodbury reached the same result by treating the case as essentially one of maritime tort. Justice Daniel dissented in support of the more restricted view.

49. 5 How. 441, 459 (U.S. 1847). Justice Woodbury wrote a long and learned dissent, in which Justices Daniel and Grier concurred, arguing for the restrictive 
An expanding conception of the scope of the admiralty power was soon to receive its most significant application in the last of the great cases of the period before the Civil War. In an earlier and insuffciently considered case, the Court had followed English precedents limiting the admiralty jurisdiction to tidewater. ${ }^{50}$ By an Act of 1845 Congress had extended admiralty jurisdiction to vessels of twenty tons and upward employed in navigation between ports of different states on the interior lakes and navigable connecting waters. ${ }^{51}$ The constitutionality of the Act was attacked in The Propeller Genesee Chief $v$. Fitzhugh, a libel in rem in a case of collision on Lake Ontario. In a truly notable opinion, Chief Justice Taney repudiated the earlier decision, accepted navigability rather than tidewater as the test best adapted to the needs of a country having "thousands of miles of public navigable water, including lakes and rivers in which there is no tide," and sustained the constitutionality of the Act of 1845 so completely as to render it superfluous. Of the waters on which the collision had occurred, he said:

"These lakes are in truth inland seas. Different States border on them on one side, and a foreign nation on the other. A great and growing commerce is carried on upon them between different States and a foreign nation, which is subject to all the incidents and hazards that attend commerce on the ocean. Hostile fleets have encountered on them, and prizes been made; and every reason which existed for the grant of admiralty jurisdiction to the general government on the Atlantic seas, applies with equal force to the lakes. There is an equal necessity for the instance and for the prize power of the admiralty court to administer international law, and if the one cannot be established neither can the other." 52

So the way was cleared in the years before the Civil War for a liberal view of the admiralty's jurisdiction of contract and related

English view. Had the collision occurred on the high seas, he conceded, it would have been governed by "the admiralty and sea laws of all nations." But it had occurred within the body of a county, between river steamers employed in local trade, "and should no more be tried without a jury, and decided by the laws of Oleron and Wisbuy, or the Consulat del Mare, or the Black Book of Admiralty, than a collision between two wagoners in the same county." Id. at 467, 472, 499.

50. The Thomas Jefferson, 10 Wheat. 428 (U.S. 1825). It is one of the unexplained paradoxes of Justice Story's judicial career that he should have been the author of the opinion in this case. In the Robert W. Parsons, 191 U.S. 17 (1903), Justice Brown observed (at 25): "The opinion is a brief one by Mr. Justice Story, and contains little more than the announcement of the general principle, and with no attempt to distinguish the English cases. It lacks wholly any display of the abundant learning which ten years before had characterized his celebrated opinion in De Lovio v. Boit, 2 Gall. 398; S.C., Fed. Cas. No. 3776."

51. 5 STAT. 726 (1845).

52. 12 How. 443, 453, 454 (U.S. 1851). Justice Daniel dissented. Further see Jackson v. Steamboat Magnolia, 20 How. 296 (U.S. 1857) ; The Eagle, 8 Wall. 15 (U.S. 1868). 
matters, a view which would bear slight resemblance to the restricted horizons of the English admiralty at the time the Constitution was adopted, but which would conform substantially to an outlook generally approved in other maritime countries. So, in the same period, the areas of admiralty power in the United States came to be defined liberally, in reliance upon a criterion better adapted to conditions in the United States, and again in harmony with views generally approved in other maritime countries. ${ }^{53}$ Lord Coke was repudiated, the tidewater test discarded, and the way cleared to bring within admiralty jurisdiction waters navigable in fact whenever or wherever it might become necessary to consider waters as an area of admiralty authority.

Immediately after the Civil War, in two important cases, the Supreme Court fortified further the law maritime as paramount and uniform national law by ruling that the proceeding in rem in a maritime cause is characteristically and exclusively maritime and is accordingly denied the state courts, the saving clause notwithstanding. In The Moses Taylor, a state judgment in a suit in rem for breach of a contract of passenger carriage by sea, prosecuted locally in reliance upon a California statute, was reversed on writ of error; ${ }^{54}$ and in The Hine $v$. Trevor the same fate befell a state judgment in another suit in rem, prosecuted in reliance upon an Iowa statute, in a case of collision on the Mississippi River. ${ }^{55}$ The contract was maritime in the one case; the tort was maritime in the other. The remedy was exclusively maritime in each. ${ }^{56}$

Thus the great contests concerning the content and scope of the admiralty jurisdiction and the admiralty's unique and exclusive procedure were waged and won within approximately the first seventyfive years of our national life. The venerable corpus of the law maritime, thus judicially acknowledged as a part of our national law, would be further elucidated in its substantive requirements, further fortified against local encroachments, and eventually much supplemented by national legislation responsive to modern needs. Ultimately, indeed, there would be an occasional recourse to treaties with other maritime

53. To what has been said above, it should be added that most of the restrictions on the early English admiralty were removed by legislation in the nineteenth century.

54. 4 Wall. 411 (U.S. 1866).

55. 4 Wall. 555 (U.S. 1866).

56. "The result of the decision was to deprive the State Courts, especially in the West, of an immense class of.cases relating to maritime contracts, collisions and other torts, over which they had hitherto exercised jurisdiction." 2 WARREN, $o p$. cit. supra note 9, at 415. The Robert W. Parsons, 191 U.S. 17 (1903) is a notable decision in the same line. One historic exception has since been recognized where the state statute authorized an in rem proceeding to forfeit for violation of local fishery regulations. C.J. Hendry Co. v. Moore, 318 U.S. 133 (1943). See Dickinson and Andrews, $A$ Decade of Admiralty in the Supreme Court of the United States, 36 CaIIF. L. Rev. 169, 172 (1948). 
nations as the unifying and supplementing process proceeded. While there is no space here for detail, a few of the more noteworthy instances or examples may be reported.

It was about the time of our Civil War that, on British initiative, the United States and an impressive number of other maritime countries adopted identic regulations for preventing collisions at sea. The Scotia was a case of collision on the high seas between a British and a United States vessel in which, if the identic regulations were applicable, the United States vessel was clearly at fault. For the American owners it was argued that the regulations were mere national laws, applicable severally to national ships, but necessarily inapplicable to an international collision. This argument the Supreme Court rejected. Said Justice Strong for a unanimous Court:

"Undoubtedly, no single nation can change the law of the sea. That law is of universal obligation, and no statute of one or two nations can create obligations for the world. Like all the laws of nations, it rests upon the common consent of civilized communities. It is of force, not because it was prescribed by any superior power, but because it has been generally accepted as a rule of conduct. Whatever may have been its origin, whether in the usages of navigation or in the ordinances of maritime states, or in both, it has become the law of the sea only by the concurrent sanction of those nations who may be said to constitute the commercial world."

So it was that the ancient usages and the classical codes became of universal obligation. "It is evident," Justice Strong continued, "that unless general assent is efficacious to give sanction to international law, there never can be that growth and development of maritime rules which the constant changes in the instruments and necessities of navigation require." The regulations for preventing collisions at sea had received a general assent. They governed the case. The opinion concluded:

"This is not giving to the statutes of any nation extraterritorial effect. It is not treating them as general maritime laws, but it is recognition of the historical fact that by common consent of mankind, these rules have been acquiesced in as of general obligation. Of that fact we think we may take judicial notice. Foreign municipal laws must indeed be proved as facts, but it is not so with the law of nations." 57

A few years later it fell to the lot of Justice Bradley to elaborate upon the same underlying ideas in what may be described fairly as a

57. 14 Wall. 170, 187, 188 (U.S. 1871). 
classical statement of the American maritime tradition. Fifty-five years earlier, in one of his inexplicable lapses, Justice Story had ruled summarily for the Court that there is no lien for repairs and necessaries furnished in the home port. ${ }^{58}$ State legislatures had enacted a miscellany of statutes to fill the gap. While the liens thus created were ultimately to be denied in rem enforcement in the state courts, they were recognized and given effect in the admiralty courts at an early date. ${ }^{59}$ The Supreme Court had vacillated in its formulation of a relevant rule of admiralty practice, first providing for the enforcement of such liens by a proceeding in rem in 1844 , then denying such enforcement in a revised rule of 1859 , and finally restoring the earlier practice in a further revision of $1872 .^{60}$ About a year before the latter revision became effective, claim to a lien for repairs and necessaries furnished in the home port was interposed in an admiralty proceeding in the federal court in Louisiana. Since the claimant had failed to record as the local statute required, and since the Admiralty Rule in force at the time authorized only a proceeding in personam, the claimant had no case. However, claimant urged strongly on appeal that the earlier decision should be reconsidered and overruled and thus presented what the Supreme Court chose to regard as "the principal question in the case."

The case was The Lottawanna. Arguing that the earlier case of The General Smith should be overruled, counsel elaborated upon the thesis that "the maritime law is part of the law of nations," that its universality is one of its "great beauties," and that uniformity had been declared to be its essence. Though obviously impressed, the majority for which Justice Bradley spoke concluded that the old rule had been relied upon too long as a rule of property and that if the inconveniences resulting from "the often intricate and conflicting state laws" were to be corrected it must be by act of Congress. Justice Bradley's opinion merits quotation at greater length than our space permits. He said in part:

"But it is hardly necessary to argue that the maritime law is only so far operative as law in any country as it is adopted by the laws and usages of that country. In this respect it is like international law or the laws of war, which have the effect of law in no country any further than they are accepted and received as such; ... Whilst it is true that the great mass of maritime law is the same in all commercial countries, yet, in each country,

58. The General Smith, 4 Wheat. 438 (U.S. 1819). Cf. De Lovio v. Boit, supra note 47 ; and see supra note 50.

59. See Peyroux v. Howard, 7 Pet. 324 (U.S. 1833).

60. See 21 Wall. 560,562 (U.S. 1874). 
peculiarities exist either as to some of the rules, or in the mode of enforcing them. Especially is this the case on the outside boundaries of the law, where it comes in contact with, or shades off into the local or municipal law of the particular country and affects only its own merchants or people in their relations to each other. Whereas, in matters affecting the stranger or foreigner, the commonly received law of the whole commercial world is more assiduously observed-as, in justice, it should be. No one doubts that every nation may adopt its own maritime code. France may adopt one; England another; and the United States a third; still, the convenience of the commercial world, bound together, as it is, by mutual relations of trade and intercourse, demands that in all essential things wherein those relations bring them in contact, there should be a uniform law founded on natural reason and justice. Hence the adoption by all commercial nations (our own included) of the general maritime law as the basis and groundwork of all their maritime regulations. . . . And thus it happens, that, from the general practice of commercial nations in making the same general law the basis and groundwork of their respective maritime systems, the great mass of maritime law which is thus received by these nations in common, comes to be the common maritime law of the world.

"... One thing, however, is unquestionable; the Constitution must have referred to a system of law coextensive with, and operating uniformly in, the whole country. It certainly could not have been the intention to place the rules and limits of maritime law under the disposal and regulation of the several States, as that would have defeated the uniformity and consistency at which the Constitution aimed on all subjects of a commercial character affecting the intercourse of the States with each other or with foreign states." 61

Justice Bradley's observations with respect to the Constitutional mandate were implemented firmly some fifty years later, though only after a prolonged contest, in a sequence of important decisions excluding the application of state workmen's compensation statutes in cases of maritime injury. Seamen had their ancient right to "maintenance and cure" and would soon have modern employers' liability under the Jones Act. But longshoremen and other harbor workers, a hardworking class of men employed in a hazardous occupation, had nothing comparable. The larger proportion of them were normally employed in fact on both land and water. In Southern Pacific Company v. Jensen, a stevedore driving a loaded electric truck off a ship was killed in an accident at the ship's end of the gangway. New York courts approved

61. 21 Wall. 558, 572-575 (1874). Justices Clifford and Field dissented. Most of the inconveniences were corrected by the Maritime Lien Act of 1910. 36 STAT. 604 , as amended by an Act of 1920, 41 STAT. 988, 46 U.S.C. $\$ 861$ (1946). 
an award of compensation under the state statute. On writ of error, the Supreme Court reversed. Compensation was not a "common law remedy" within the meaning of the saving clause. The award was an invasion of admiralty's exclusive jurisdiction and an impairment of the uniformity of national maritime law. Referring to the constitutional grant of admiralty jurisdiction in Article 3, section 2, and to the "necessary and proper" clause in Article 1, section 8, Justice McReynolds for the majority said:

"Considering our former opinions, it must now be accepted as settled doctrine that in consequence of these provisions Congress has paramount power to fix and determine the maritime law which shall prevail throughout the country. ... And further, that in the absence of some controlling statute the general maritime law as accepted by the federal courts constitutes part of our national law applicable to matters within the admiralty and maritime jurisdiction."

After quoting from Justice Bradley's opinion in The Lottawanna, Justice McReynolds continued:

"It would be difficult, if not impossible, to define with exactness just how far the general maritime law may be changed, modified,

' or affected by state legislation. That this may be done to some extent cannot be denied. . . Equally well established is the rule that state statutes may not contravene an applicable act of Congress or affect the general maritime law beyond certain limits. ... And plainly, we think, no such legislation is valid if it contravenes the essential purpose expressed by an act of Congress or works material prejudice to the characteristic features of the general maritime law or interferes with the proper harmony and uniformity of that law in its international and interstate relations. This limitation, at the least, is essential to the effective operation of the fundamental purposes for which such law was incorporated into our national laws by the Constitution itself." 62

Congress responded to the Jensen decision, not by enacting such a general statute as the Court had virtually invited it to enact, but by amending the saving clause to save to claimants "the rights and remedies under the workmen's compensation law of any State." 63 This amend-

62. 244 U.S. 205, 215, 216 (1917). Justices Holmes, Pitney, Brandeis and Clarke dissented. Justice Holmes thought that in the silence of Congress "the wholly inadequate maritime law of the time of the Constitution" should be supplemented from the statute or common law of the states. Justice Pitney developed at length the thesis that common law courts had been left a concurrent jurisdiction and that admiralty and common law courts should apply each their own substantive law in resolving a maritime case. Justices Brandeis and Clarke concurred in both dissenting opinions.

63. 40 STAт. 395 (1917). 
ment the Supreme Court promptly held an unconstitutional delegation of legislative power to the states and an unconstitutional impairment of "the harmony and uniformity which the Constitution not only contemplated but actually established." Speaking for the majority in Knickerbocker Ice Company v. Stewart, Justice McReynolds said:

"We think the enactment is beyond the power of Congress. Its power to legislate concerning rights and liabilities within the maritime jurisdiction and remedies for their enforcement, arises from the Constitution, as above indicated. The definite object of the grant was to commit direct control to the Federal Government; to relieve maritime commerce from unnecessary burdens and disadvantages incident to discordant legislation; and to establish, so far as practicable, harmonious and uniform rules applicable throughout every part of the Union." 64

Once more the Congress reacted by adding claims to compensation under local statutes to the saving clause. The new amendment, except as it excluded compensation for injuries to or death of "the master or members of the crew of a vessel," was substantially like the old. ${ }^{65}$ This exclusion proved wholly insufficient to meet the Court's objection to the prior enactment. Said Justice McReynolds for the majority in State of Washington v. Dawson \& Company: "the doctrine of Knickerbocker Ice Co. v. Stewart, to which we adhere, permits no other conclusion." The opinion concluded:

"This cause presents a situation where there was no attempt to prescribe general rules. On the contrary, the manifest purpose was to permit any State to alter the maritime law and thereby introduce conflicting requirements. To prevent this result the Constitution adopted the law of the sea as the measure of maritime rights and obligations. The confusion and difficulty, if vessels were compelled to comply with the local statutes at every port, are not difficult to see. Of course, some within the States may prefer local rules; but the Union was formed with the very definite design of freeing maritime commerce from intolerable restrictions incident to such control. The subject is national. Local interests must yield to the common welfare. The Constitution is supreme." 68

After the decision in State of Washington $v$. Dawson \& Co. the Congress turned, as we may now see that it should have turned in the

64. 253 U.S. 149, 164 (1920). Justices Holmes, Pitney, Brandeis and Clarke again dissented.

65. 42 STAT. 634 (1922).

66. 264 U.S. 219, 228 (1924). Justice Holmes would have been glad to see a limit set to the principle of the Jensen case, but left it "to those who think the principle right to say how far it extends." Only Justice Brandeis wrote a dissenting opinion. His dissent, in its twentieth century setting, was in some respects reminiscent of to the more notable admiralty dissents of an earlier period. 
first instance, to the enactment of a national compensation statute responsive to the requirement of uniformity upon which the Supreme Court had insisted. The Longshoremen's and Harbor Workers' Compensation Act of $1927^{67}$ stopped short of providing a comprehensive system for the maritime workers concerned. Its coverage was restricted to disability or death resulting from "an injury occurring upon the navigable waters of the United States (including any drydock)" and then only if recovery "through workmen's compensation proceedings may not validly be provided by State law." Within its scope, however, it was national and uniform. Location case by case of the line between national and state authority was left to the courts. There would be a multiplicity of peripheral problems, needless to say, as well as problems of interpretation. ${ }^{68}$ For present purposes it is enough to note that the statute withstood all attacks upon its constitutionality. Said Chief Justice Hughes for the Court: "the general authority of the Congress to alter or revise the maritime law which shall prevail throughout the country is beyond dispute." 60

Here it should be interpolated that much of the more recent progress of the maritime law has been achieved through national legislation. The Limited Liability Act of $1851,^{\mathbf{7 0}}$ the Harter Act of $1893^{\mathbf{7 1}}$ and the Federal Maritime Lien Act of $1910,{ }^{72}$ among others, had antedated the Jensen controversy. While the controversy precipitated by the Jensen decision was at its height, the Congress was engaged in bringing to enactment the Merchant Marine Act of $1920,{ }^{73}$ the Death on the High Seas Act of $1920,{ }^{74}$ and the Ship Mortgage Act of $1920 .{ }^{75}$ Later legislation, like much of the earlier, has been part of a continuing effort to keep maritime law abreast of the needs of seaborne commerce and also to develop it in harmony with the laws of other maritime countries. ${ }^{76}$ In a number of instances there has been recourse to the

67. 44 Stat. 1424 (1927).

68. See Dickinson and Andrews, supra note 56, at 176-182.

69. Crowell v. Benson, 285 U.S. 22, 39 (1932).

70. 9 StAт. 635 (1851). There is report of some interesting history in Norwich Company v. Wright, 13 Wall. 104 (U.S. 1871).

71. 27 Stat. 445 (1893).

72. 36 Stat. 604 (1910). This legislation was revised slightly and re-enacted as part of the Merchant Marine Act of 1920. 41 STAT. 988 (1920), 46 U.S.C. $\$ 861$ (1946).

73. 41 STAT. 988 (1920), 46 U.S.C. $\$ 861$ (1946). Section 33 of this statute is the so-called Jones Act which provides employers' liability for seamen. On the constitutionality of the Jones Act and its effect upon local law, see Panama Railroad Company v. Johnson, 264 U.S. 375 (1924) ; Lindgren v. United States, 281 U.S. 38 (1930); and O'Donnell v. Great Lakes Dredge \& Dock Co., 318 U.S. 3 (1943).

74. 41 STAT. 537 (1920), 46 U.S.C. $\$ 761$ (1946).

75. 41 Stat. 1000 (1920), 46 U.S.C. $\$ 921$ (1946).

76. For a notable example, see the Carriage of Goods by Sea Act of 1936, 49 STAT. 1207 (1937), 46 U.S.C. $\$ 1300$ (1946). 
treaty-making power to round out the effort. ${ }^{77}$ Since the subjectmatter has been international for more than two thousand years, and in the United States is committed in its entirety to the national government, there has been and could be no serious question as to the propriety of such recourse.

This part of our study may be concluded appropriately with a note of the Supreme Court's response to an attack upon the constitutionality of the Ship Mortgage Act mentioned above. The attack was aimed at the broad range of the statute and fortified by the circumstance that the Court had ruled, in one of its earlier and less considered opinions, that a ship mortgage is not maritime. ${ }^{78}$ To encourage investment in shipping and shipping securities, the new statute made such mortgages maritime and defined their priorities with meticulous care, all without limitation upon the use which might be made of the proceeds of loans thus secured. Issues as to constitutionality were presented in suits in admiralty to foreclose two ship mortgages the proceeds of which had been largely applied for non-maritime purposes, The constitutionality of the Act was sustained in reliance upon the grant of judicial power with respect to "all cases of admiralty and maritime jurisdiction" and the legislative power "to make all laws which shall be necessary and proper." The Court did not overlook a suggestion in the earlier opinion that there might be legislative power. Speaking for a unanimous Court, Chief Justice Hughes said:

". . . the grant presupposed a 'general system of maritime law' which was familiar to the lawyers and statesmen of the country, and contemplated a body of law with uniform operation. . . . The framers of the Constitution did not contemplate that the maritime law should remain unalterable. The purpose was to place the entire subject, including its substantive as well as its procedural features, under national control. . . . The Congress thus has paramount power to determine the maritime law which shall prevail throughout the country." 79

77. See Convention Retating to Assistance and Salvage at Sea (1910) 37 Stat. 1658; Convention and Regulations for Promoting Safety of Life at Sea (1929) 50 Stat. 1121; Convention Establishing LoAd Lines to SHips of INTERnational Voyage (1930) 47 Stat. 2228; Convention Respecting OfFicers' Competency Certificates (1936) 54 Stat. 1683; Convention Respecting Shipowners' LIABILITY In CASE of SickNess, INJURY, or DEATH of SEAMEN (1936) 54 Stat. 1693; Convention Respecting Mintmum Age for Employment of Children AT SEA (1936) 54 Stat. 1705.

78. Bogart v. The Steamboat John Jay, 17 How. 399 (U.S. 1854).

79. Detroit Trust Co. v. The Thomas Barlum, 293 U.S. 21, 43 (1934). After referring to English legislation enlarging the admiralty jurisdiction of ship mortgages, and with a footnote to the laws of several of the states of western Europe, Chief Justice Hughes said (at 49) : "This response 'to the exigencies of commerce' has had its counterpart in the legislation of other European States. It may be said that the 'general maritime law' takes cognizance of mortgages of ships, provides for their registration, and establishes rules with respect to priorities." 
The "general system of maritime law" has had some rough sailing in the United States, as we have seen, and storms chiefly of states' rights origin have at times compelled a little deviation. It could hardly have been otherwise in a young nation organized on federal principles, We may see now, nevertheless, that the main course was charted clearly in the beginning and that it has been as steadily pursued. The venerable corpus of the customs and codes of the sea had a vitality which was not to be denied. In the result the law maritime has been received and adjusted to federalism in a long sequence of judicial decisions. It has been supplemented extensively by national legislation which has been generally in basic harmony with practices prevailing elsewhere in the maritime world. It has even been unified internationally, with respect to some of its concerns, through participation in multipartite treaties of legislative effect. An impressive system, it is firmly established as a part of the national law of the United States.

\section{IV.}

The progress in judicial administration of what for convenience we have called the law of states has encountered neither the frustrations of the national law of offences nor the confusions incident to judicial overreaching which developed so soon after the initial recourse to a national law of merchants. Fundamentally the progress of the law of states in the United States has been more like the parallel and oft-related progress of the law maritime. Where differences in the unfolding pattern are observed, there are two circumstances among others which may have contributed something to the result.

In the first place, it is to be remembered that the law of states was an immature law when the Constitution was adopted. While some of its practices had their roots in a remote past, it could boast no such antiquity, as a system, as either the law of merchants or the law maritime. Indeed, it had hardly arrived at the threshold of its own systematization. Its recent development had been in response to the requirements of an emerging European state community and in general traced no further back than the late sixteenth or the early seventeenth century. Grotius had atthored the first attempt at comprehensive treatment in 1625, a mere one hundred and fifty years before the American Revolution. After Grotius there had been other treatises, including a number which would eventually rank as classics, but even the more realistic of the classical writers inclined at times to round out the gaps or imperfections of their subject in some rather speculative discourse. In the customs and treaties which had accumulated there 
was evidence enough of an emerging body of practice fairly described as universal, but it was still amorphous.

In the second place, in understanding of all this and with a notable foresight, the framers of the Constitution provided boldly for the law of states by combining an impressive enumeration of defined powers with broader generalizations calculated to serve well the more embracing purpose. As to everything external, the United States was to be "one nation only, firmly hooped together." It was not thought sufficient merely to identify a subject-matter or to include it by implication within the broad range of a general power. War, peace, treaties, commerce, captures, piracies and felonies on the seas, offences against the Law of Nations, the naturalization of aliens, diplomatic and consular intercourse, and controversies between a state or its citizens and foreign states or their citizens or subjects were covered in express provisions. The aggregate was well-nigh repetitious in its emphasis upon national power. There were also broader generalizations and necessary implications which would include more. Subject only to such limitations as were express or implicit in the American system of constitutional government, the national power under or with respect to the law of states would embrace, as the authors of the Declaration of Independence had anticipated, "all other acts and things which Independent States may of right do."

In one view, the law of states would contribute significantly to an American conception of nationhood. In another, it would provide an indispensable source of reference as competent national authorities proceeded to fashion a law with respect to the conduct of international relations. We are here concerned chiefly with the contribution of judicial authorities. Obviously there is no space for more than a sampling. However, if the sampling may be of matter sufficiently typical from topics sufficiently varied, the progress of the law of states in judicial administration may be at least fitfully illuminated. The subject matter of our attempt at a fitfull illumination will be taken from the law of territory, the law of nationality and the law of treaties.

There is nothing in the Constitution which provides in terms for the acquisition of additional territory or territorial rights. It will be recalled that Jefferson entertained doubts about the constitutionality of the Louisiana purchase and even toyed briefly with the idea of a constitutional amendment. ${ }^{80}$ The acquisition was consummated notwithstanding; and it was not long after that the acquisition of Florida from Spain was consummated by another treaty of cession. The latter cession soon afforded Chief Justice Marshall an opportunity to for-

80. See 2 Schachner, Thomas JefFerson, 725-726, 745-754 (1951). 
mulate broadly one of his more significant statements with respect to the national power in matters of international concern. The American Insurance Co. $v$. Canter was a case between underwriters to whom cargo had been abandoned and a purchaser at a sale ordered by a Florida territorial court to satisfy the claims of salvors. The principal question was whether the territorial court was a court of competent jurisdiction. When the case reached the Supreme Court, the arguments of eminent counsel ranged widely and the Chief Justice elected to begin the substantive part of his opinion with a dictum of enduring consequence. "The course which the argument has taken," he said, "will require, that, in deciding this question, the Court should take into view the relation in which Florida stands to the United States." He continued: "The Constitution confers absolutely on the government of the Union, the powers of making war, and of making treaties; consequently, that government possesses the power of acquiring territory, either by conquest or by treaty." 81

There is no space to detail here the progressive development in later judicial applications or affirmations of the doctrine thus tersely formulated in Chief Justice Marshall's famous dictum. Needless to say, the history of the United States has been a history of territorial expansion, first across the continent, then overseas. Territorial sovereignty unrestricted by the terms of its acquisition has come to the United States by treaties of outright cession, by treaties for the settlement of boundaries, by joint resolutions of Congress, and in an instance of minor importance by exchange of diplomatic notes. Rights of territorial sovereignty transferred for an agreed purpose or subject to agreed limitations have come by treaty, by executive agreement, and recently by trusteeship agreement with the United Nations. The courts have been called upon many times to record a view of the national power and have responded consistently in approval, given expressly or implicitly, of the exercise of power through the procedures invoked. ${ }^{82}$ Nor has judicial acquiescence been a mere manifestation of

81. 1 Pet. 511, 541-542 (U.S. 1828).

82. See Stewart v. Kahn, 11 Wall. 493, 507 (U.S. 1870); United States v. Fuckabee, 16 Wall. 414, 434 (U.S. 1872); Mormon Church v. United States, 136 U.S. 1, 42 (1890); De Lima v. Bidwell, 182 U.S. 1, 195-196 (1901); Downes v. Bidwell, 182 U.S. 244, 300 et seq. (1901); Dorr v. United States, 195 U..S. 138, 140 (1904); Wilson v. Shaw, 204 U.S. 24, 32 (1907); Hooven \& Allison Co. v. Evatt, 324 U.S. 652, 673 (1945). In Downes v. Bidwell (at 304), Justice White referred to "the vast extension of the territory of the United States brought about since the existence of the Constitution by substantially every form of acquisition known to the law of nations." In Mormon Church v. United States (at 42), Justice Bradley remarked: "The incidents of these powers are those of national sovereignty, and belong to all independent governments. The power to make acquisitions of territory by conquest, by treaty and by cession is an incident of national sovereignty." On acquisition followed by relinquishment, and the effect of relinquishment upon nationality, see Cabebe v. Acheson, 183 F.2d 795 (9th Cir. 1950). 
judicial caution when confronted with an exercise of political power. It has been clear enough from the beginning that the courts have resolved the issues presented without restraining doubts concerning this aspect of the national power in matters of international concern.

Even before the American Insurance Co. case reached the Supreme Court, Chief Justice Marshall had found an occasion to discuss the acquisition of territory by discovery and occupation. Herein was the initial source of all territorial rights within the boundaries of the older states as acknowledged in the treaty of peace with Great Britain. ${ }^{83}$ Herein was a further resource in the affirmation of national power. By an Act of 1856, the Congress provided for the acquisition by discovery and occupation of islands, rocks or keys valuable for their deposits of guano. ${ }^{84}$ Years later the constitutionality of this act was challenged in a case arising out of a conviction of murder committed on an island so acquired. Sustaining the act for a unanimous Court, Justice Gray thought it enough to say:

"By the law of nations, recognized by all civilized States, dominion of new territory may be acquired by discovery and occupation, as well as by cession or conquest. . . . This principle affords ample warrant for the legislation of Congress concerning guano islands." 85

There has been similar reliance upon the Law of Nations and treaties in the business of finding judicial solution for a multiplicity of problems arising out of territorial acquisition. It has been agreed generally that governmental powers go with the transfer but that the law in force in the territory transferred continues operative until changed by the succeeding sovereign. Again, the Constitution is not explicit; and again we find the course of judicial decision charted initially in a notable dictum of the earlier years. It was in the same opinion in American Insurance Co. v. Canter, referring to the "usage of the world," that Chief Justice Marshall remarked:

"On such transfer of territory, it has never been held, that the relations of the inhabitants with each other undergo any change. Their relations with their former sovereign are dissolved, and new relations are created between them, and the government which has

83. Johnson v. McIntosh, 8 Wheat. 543 (U.S. 1823).

84. 11 Stat. 119 (1856), 48 U.S.C. \$1411 (1946).

85. Jones v. United States, 137 U.S. 202, 212 (1890). In support of the principle, Justice Gray cited the treatises of Vattel, Wheaton, Halleck, Phillimore and Calvo. The same principle has been invoked recently, in a case concerning Palmyra Island, in support of an acquisition by Hawaii which passed thereafter by annexation to the United States. United States v. Fullard-Leo, 133 F.2d 743 (9th Cir.), cert. denied, 319 U.S. 748 (1943). For the later decisions with respect to vested property rights on Palmyra, see note 89 infra. 
acquired their territory. The same Act which transfers their country, transfers the allegiance of those who remain in it; and the law, which may be denominated political, is necessarily changed, although that which regulates the intercourse, and general conduct of individuals, remains in force, until altered by the newly created power of the state." 86

The broad principle thus felicitously formulated was from the Law of Nations. It was as surely a part of national law as though it had been incorporated in terms in the Constitution. It has since had an uninterrupted acceptance and a wide range of applications in the opinions of both state and federal courts. ${ }^{87}$

It has likewise been agreed generally that, while rights in public property go with the transfer, vested rights in private property are to be respected by the succeeding sovereign. As much has usually been stipulated in the treaty or agreement by which territory has been acquired. More embracing principles, in the light of which both the instrument of acquisition and national implementing legislation are to be construed, have been elaborated in reliance upon the Law of Nations. On occasion, indeed, there has been express or implicit reliance upon the more embracing principles as a basis of decision. Five years after the decision in American Insurance Co. v. Canter, another case reached the Supreme Court on appeal from the decision of a Florida court confirming title to land claimed upon a Spanish grant. The case required an interpretation and application of the treaty of cession and of statutes enacted for the settlement of land claims in the ceded territory. Concerning one of the treaty's provisions, it was observed that a restrictive interpretation would work a wrong to individuals "condemned by the practice of the whole civilized world." As regards another, it was remarked that it conformed exactly to "the uniformly received doctrine of the law of nations." The case was United States $v$. Percheman, in which Chief Justice Marshall for a unanimous Court found occasion to say:

"It may not be unworthy of remark, that it is very unusual, even in cases of conquest, for the conqueror to do more than to displace the sovereign and assume dominion over the country. The modern usage of nations, which has become law, would be violated;

86. 1 Pet. 511, 542 (U.S. 1828).

87. See Fremont v. United States, 17 How. 542, 557 (U.S. 1854) ; United States v. Perot, 98 U.S. 428,430 (1878); Chicago, R. I. \& P. Ry. v. McGlinn, 114 U.S. 542, 546 (1885); Ortega v. Lara, 202 U.S. 339, 342 (1906); Vilas v. City of Manila, 220 U.S. 345, 356-358 (1911). In the latter case (at 357), it was said: "Such a conclusion is in harmony with the settled principles of public law as declared by this and other courts and expounded by the text books upon the laws of war and international law." 
that sense of justice and of right which is acknowledged and felt by the whole civilized world would be outraged, if private property should be generally confiscated, and private rights annulled. The people change their allegiance; their relation to their ancient sovereign is dissolved: but their relations to each other, and their rights of property, remain undisturbed. If this be the modern rule even in cases of conquest, who can doubt its application to the case of an amicable cession of territory? Had Florida changed its sovereign by an act containing no stipulation respecting the property of individuals, the right of property in all those who became subjects or citizens of the new government would have been unaffected by the change." 88

It is true enough that much of what was said here was less than strictly necessary to decision. It is no less true that there was formulated in what was said a doctrine which was to be frequently and consistently affirmed over the ensuing years as territorial expansion brought to the courts a host of problems with respect to the effect of transfers of territory upon property rights. ${ }^{80}$

The territorial expansion of the United States has been productive also of an impressive body of judicial business with respect to disputed limits or boundaries. Here there has been a development of national law in conformity with international principles which is in important respects unique. States of the United States have a unique position in the federal structure and many of the boundaries now interstate have been at some time international. Whether prompted by federalism or by history, or both, the Supreme Court from the beginning has resolved interstate boundary disputes in recourse to the Law of Nations. So, where the boundary is a navigable river or other navigable waterway, the international doctrine of the thalweg has provided an acceptable solution. Familiar principles governing the effect of accretion and avulsion have been as consistently applied. Principles of prescription

88. 7 Pet. 51, $86-88$ (U.S. 1833). See Soulard v. United States, 4 Pet. 511 (U.S. 1830).

89. See Mitchel v. United States, 9 Pet. 711, 734 (U.S. 1835); Jones v. McMasters, 20 How. 8,20 (U.S. 1857); Strother v. Lucas, 12 Pet. 410, 435-436 (U.S. 1838) ; United States v. Chaves, 159 U.S. 452, 457, 458, 464 (1895); Maish v. Arizona, 164 U.S. 599, 608 (1896); Shapleigh v. Mier, 299 U.S. 468, 470 (1937); United States v. Fullard-Leo, 331 U.S. 256 (1947). In the latter case (at 269); Justice Reed for the majority assumed that discovery and occupation "gave Hawaii not only sovereignty over Palmyra but also the power to grant the lands of the newly annexed islets as part of its public lands to private owners." See note 85 supra. Justice Reed continued: "We take judicial notice of the laws of Hawaii prior to its annexation as a part of our domestic laws. .. . While in matters of local law the federal courts defer to the decisions of the territorial courts, we are dealing here with a problem of federal law-the United States seeks to quiet its title to land now claimed by virtue of Hawaiian cession." An adverse title was quieted in private owners on the theory of a lost grant. Cf. Clearfield Trust Co. v. United States, supra note 41 . 
have had recognition and a rather notable development. The leading treatises on the Law of Nations have been used freely and have provided support for the conclusions reached. ${ }^{90}$

There have been few substantive distinctions of consequence between the judicial approach to boundary problems which are interstate and to those which are truly international; though problems of the latter sort concerning boundaries between the United States and neighboring nations to the north or south have reached the courts less frequently and generally on questions of treaty interpretation. ${ }^{91}$ On the other hand, the maritime frontier between the United States and nations interested in the highways and resources of the sea has become the subject over the years of a considerable body of case law. Ports, harbors, bays, roadsteads and the like have had occasional judicial attention. The marginal seas, described paradoxically in recent years as the belt of "territorial waters," have had a good deal more. Here, as elsewhere in matters of international concern, there has been much reliance upon the Law of Nations. ${ }^{92}$ The tidelands cases of current interest are among the latest in an unfolding pattern of judicial recognition of international responsibility and corresponding national power. ${ }^{93}$

From the law of territory we may now turn to the law of nationality. As is well known, the topic has had a troubled history, particularly in the years before the Civil War. Until the Fourteenth Amendment, relevant constitutional provisions charted no very obvious course. The usages and agreements of nations had substantially less to contribute. We shall observe a progress of national law, nevertheless, which resembles in important respects the progress hitherto observed with respect to the law of territory.

Except for the legislative power vested in Congress "to establish an uniform rule of naturalization" (Art. I, $\$ 8, \pi 4$ ), the Constitution as originally adopted was less than explicit with respect to nationality. Along with other requirements, the representative or senator must

90. Applying the thalweg doctrine, see Iowa v. Illinois, 147 U.S. 1 (1893); Louisiana v. Mississippi, 202 U.S. 1 (1906) ; Arkansas v. Tennessee, 246 U.S. 158 (1918) ; Minnesota v. Wisconsin, 252 U.S. 273 (1920) ; New Jersey v. Delaware, 291 U.S. 361 (1934). Concerning accretion and avulsion, see also Nebraska v. Iowa, 143 U.S. 359 (1892) ; Missouri v. Nebraska, 196 U.S. 23 (1904) ; Missouri v. Kansas, 213 U.S. 78 (1909) ; Cissna v. Tennessee, 246 U.S. 289 (1918). Concerning prescription, see Indiana v. Kentucky, 136 U.S. 479 (1890); Michigan v. Wisconsin, 270 U.S. 295 (1926).

91. See Pigeon River Improvement, Slide \& Boom Co. v. Cox, 291 U.S. 138 (1934); Shapleigh v. Mier, 299 U.S. 468 (1937).

92. See Church v. Hubbart, 2 Cranch 187 (U.S. 1804); Manchester v. Massachusetts, 139 U.S. 240 (1891); Cunard Steamship Co. v. Mellon, 262 IU.S. 100 (1923).

93. United States v. California, 332 U.S. 19, 804 (1947); United States v. Louisiana, 339 U.S. 699, 340 U.S. 899 (1950) ; United States v. Texas, 339 U.S. 707, 340 U.S. 848,900 (1950). 
have been "a citizen of the United States" for at least a minimum period (Art. I, $\S 2, \pi 2$ and Art. I, $\$ 3, \Uparrow 3$ ). Only "a natural born citizen of the United States, at the time of the adoption of this Constitution," was eligible to the office of president (Art. II, $\$ 1, \mathbb{I} 5$ ). The judiciary article referred to "citizens" of the several states (Art. III, $\$ 2, \mathbb{1} 1$ ), as did the privileges and immunities clause of the ensuing article (Art. IV $, \S 2, \mathbb{I} 1$ ); and the judiciary article referred also to foreign citizens or subjects. ${ }^{94}$

With no more to guide, the transition from state to United States citizenship was sure to be confused, particularly in the years of controversy concerning states' rights and the slavery question. One writer has identified the whole period before the Civil War as that in which United States citizenship developed "from its origin as a stepchild of state citizenship to its official emancipation from state domination by the Fourteenth Amendment." 95 It is to be observed, notwithstanding, that the "emancipation" was anticipated in the Supreme Court long before the Civil War-at about the time, indeed, that matters of territorial acquisition and succession hitherto reviewed were before the Court-and again with considerable discussion of the Law of Nations. The occasions were provided by cases concerned with problems of allegiance and alienage arising out of the Revolution and in particular with the security of property rights of British subjects which treaties with Great Britain had sought to assure. ${ }^{96}$. In one of these cases, in which the South Carolina court was reversed on writ of error, Justice Story remarked of the rights deriving from allegiance that "Those political rights do not stand upon the mere doctrines of municipal law, applicable to ordinary transactions, but stand upon the more general principles of the law of nations." 97

After the Civil War, the earlier judicial assumptions were affirmed and the whole subject was neatly clarified in the opening sentence of the Fourteenth Amendment: "All persons born or naturalized in the United States, and subject to the jurisdiction thereof, are citizens of the United States and of the State wherein they reside." Thirty years later Justice Gray provided the profession with a classical commentary on this opening sentence in his famous opinion in the case of United States v. Wong Kim Ark. In support of a ruling that a child born

94. See also U.S. Const. Amenn. XI with respect to suits against a state and U.S. CONST. AMEND. XII with respect to the vice president's eligibility.

95. Roche, The Early Development of United States Citizenship, 1 (1949).

96. See Inglis v. The Trustees of the Sailor's Snug Harbour, 3 Pet. 99, 120-127, 154-171 (U.S. 1830); and Shanks v. Dupont, 3 Pet. 242, 246-249 (U.S. 1830).

97. Shanks v. Dupont, id. at 248. For the states' rights view which the Court rejected, see Justice Johnson's dissent. 
in the United States of Chinese parents, themselves ineligible to citizenship, was a citizen of the United States by birth, the opinion reviewed the entire subject at common law and under the Constitution in both its national and its international aspects. The ancient rule of citizenship by birth within the dominion and subject to the jurisdiction was found to be in complete accord with a permissive international practice. Citizenship of the United States was indisputably the primary citizenship in this country. The amendment was "declaratory of existing rights, and affirmative of existing law." 98

Meanwhile the United States had accumulated a spate of troubles in its endeavors to protect naturalized citizens against the competing claims advanced in countries of origin. Indelible allegiance was the doctrine of the English common law. It was even more firmly entrenched in the law of many European nations. In the United States, on the other hand, experience had fortified a growing conviction that the doctrine was in fundamental conflict with principles which a nation heavily dependent upon immigration must espouse. In 1868, the day before ratification of the Fourteenth Amendment was proclaimed, the Congress by preamble declared expatriation "a natural and inherent right of all people," by enactment repudiated for the United States every vestige of indelible allegiance as "inconsistent with the fundamental principles of this government," and by further enactment affirmed the right of naturalized citizens abroad to "the same protection of persons and property that is accorded to native-born citizens in like situations and circumstances." 99 The same year signalized the initiation of what was to become a long series of conventions or treaties designed to mitigate or remove conflicting claims to the allegiance of naturalized citizens. In the setting so prepared, and implemented by fiat of Congress and exercise of the treaty power, courts of the United States would eventually become much concerned with the "right of expatriation" of citizens of the United States.

The first general statute defining acts of expatriation was enacted in 1907.100 One of its sections provided that "any American citizen shall be deemed to have expatriated himself when he has been naturalized in any foreign state. . . . or when he has taken an oath of allegiance to any foreign state," and another that "any American woman who marries a foreigner shall take the nationality of her husband." The constitutionality of the latter provision was first challenged in the Supreme Court in Mackenzie v. Hare. A native-born resident

98. 169 U.S. 649,688 (1898).

99. 15 Stat. 223 (1868), 8 U.S.C. $\$ 800$ (1946).

100. 34 StAт. 1228 (1907), as amended 8 U.S.C. $\$ 801$ (1946). 
American woman had married a British national here in 1909 and the couple had continued to reside in the United States. The lady sought by mandamus in the state courts to compel her registration as a voter. Mandamus was denied and on writ of error the decision of the state court was affirmed. In the Supreme Court the arguments for and against the validity of the expatriation statute took "a wide range through the principles of the common law and international law and their development and change." The Court was not disposed to view it as a case of involuntary expatriation. Rather it was a case of "a condition voluntarily entered into, with notice of the consequences." However much of the ancient identity of husband and wife had been retained in deference to domestic policy, the identity had "greater purpose and, it may be, necessity, in international policy." Said Justice McKenna for the Court:

"As a government, the United States is invested with all the attributes of sovereignty. As it has the character of nationality it has the powers of nationality, especially those which concern its relations and intercourse with other countries. We should hesitate long before limiting or embarrassing such powers." 101

The deference for a particular international policy manifested in Mackenzie v. Hare soon lost all relevance in consequence of changing opinion with respect to the nationality of married women. ${ }^{102}$ The major premise of the opinion continued unquestioned, nevertheless, and the problems multiplied. In Perkins v. Elg the Supreme Court ruled that a child born in the United States and taken during minority to the country of the parents' origin, the parents there resuming their original citizenship, retained a right at majority to elect retention of the United States citizenship acquired at birth. The Court was "fully conscious of the problems incident to dual nationality," but to cause a loss of citizenship by birth in the absence of statute or treaty having that effect, said Chief Justice Hughes, "there must be voluntary action and such action cannot be attributed to an infant. whose removal to another country is beyond his control and who during minority is incapable of a binding choice." 103

There was approved in 1940 "An Act to revise and codify the nationality laws of the United States into a comprehensive nationality code." 104 This Act includes no less than eight separate provisions for

101. 239 U.S. 299, 311 (1915).

102. See Act of 1922, 42 Stat. 1021; Act of 1940, $\$ \$ 317,504,54$ Stat. 1137, 1146, 1173 (1940), 8 U.S.C. \$ 501 et seq. (1946).

103. 307 U.S. 325, 334, 348 (1939). See Act of 1940, § 401, 54 Stat. 1137, 1168 $(1940)$. 8 U.S.C. $\$ 501$ et seq. (1946). Cf. Savorgnan v. United States, 338 U.S. 491 (1950); Mandoli v. Acheson, 344 U.S. 135 (1952).

104. 54 STAt. 1137 (1940), 8 U.S.C. $\$ 501$ et seq. (1946). 
loss of nationality by a national of the United States, whether a national by birth or by naturalization, and additional discriminatory provisions governing the naturalized national's loss of nationality by residence abroad. ${ }^{105}$ The statute's application has produced much judicial business which it would serve no present purpose to review here. It is enough to observe that within the broad limits of a permissive Law of Nations, and subject only to internal limitations as yet imperfectly defined, the United States has all powers of nationality, "especially those which concern its relations and intercourse with other countries." This is not to suggest that national governmental powers with respect to nationality are unlimited. There is no such thing as unlimited governmental power in the United States. It is to suggest that, as in matters arising under the treaty power to be considered presently, the limitations are to be "ascertained in a different way." 106

By way of rounding out our sampling of the judicial approach to problems of nationality, we should say something of aliens; and first of their exclusion. The leading case, reported as The Chinese Exclusion Case, was one of exceptional hardship. A Chinese laborer had resided lawfully in the United States for some twelve years as permitted by treaty with China and implementing legislation. In 1887, he visited China carrying a certificate from United States authorities which in terms entitled him to return. Returning in 1888, he arrived in the United States one week after the effective date of an act of Congress which, in conflict with the prior treaty, had invalidated his certificate. The treaty and the act of Congress were on a parity under the Constitution, it was assumed, and if in clear conflict the later in time must control. It was argued, however, that the laborer had a right to re-enter which the Congress could not thus arbitrarily annul. To this the Court replied that the power to exclude aliens was an incident of national sovereignty and that the legislative decision to exercise the power was conclusive upon the judiciary. If an international wrong had been done, relief must be sought elsewhere and by other procedures. Said Justice Field for an unanimous Court:

"While under our Constitution and form of goverment the great mass of local matters is controlled by local authorities, the United

105. Sections 401-410, 54 STAT. 1137, 1168 (1940), 8 U.S.C. $\$ 501$ et seq. (1946). See Roche, The Loss of American Nationality -The Development of Statutory Expatriation, 99 U. OF PA. L. REV. 25 (1950).

106. Justice Holmes, in Missouri v. Holland, 252 U.S. 416, 433 (1920). A thoughtful student of the problem has suggested that "The legitimate end of an expatriation statute is to eliminate international problems of nationality by establishing standards by which it can be determined when an American has transferred his allegiance to another sovereign." Roche, supra note 105, at 70. Patently the problems of legitimate end or limitation merit more attention than they have hitherto received. 
States, in their relation to foreign countries and their subjects or citizens are one nation, invested with powers which belong to independent nations, the exercise of which can be invoked for the maintenance of its absolute independence and security throughout its entire territory. The powers to declare war, make treaties, suppress insurrection, repel invasion, regulate foreign commerce, secure republican governments to the States, and admit subjects. of other nations to citizenship, are all sovereign powers, restricted in their exercise only by the Constitution itself and considerations of public policy and justice which control, more or less, the conduct of all civilized nations." 107

A few years later like reasoning prevailed in a case of expulsion. Speaking for the majority, Justice Gray said: "The right of a nation to expel or deport foreigners, who have not been naturalized or taken any steps towards becoming citizens of the country, rests upon the same grounds, and is as absolute and unqualified as the right to prohibit and prevent their entrance into the country." Again the statements of leading commentators on the Law of Nations were reviewed, and again it was emphasized that "The United States are a sovereign and independent nation, and are vested by the Constitution with the entire control of international relations, and with all the powers of government necessary to maintain that control and to make it effective." 108

Coming finally to the law of treaties, we are at the point of sampling something from the law of states which had been the subject of disillusioning experience under the Articles of Confederation, which was much to the fore in the thinking of statesmen concerned with revision of the Articles, and which was never out of mind in the days of the Constitutional Convention. The Constitution as adopted provided for national authority in terms which are explicit and embracing. The power to make treaties is vested in the President by and with the advice and consent of the Senate "provided two-thirds of the Senators present

107. 130 U.S. 581, 604 (1889). In Nishimura Ekiu v. United States, 142 U.S. 651 (1892), Justice Gray said (at 659): "It is an accepted maxim of international law, that every sovereign nation has the power, as inherent in sovereignty, and essential to self-preservation, to forbid the entrance of foreigners within its dominions, or to admit them only in such cases and upon such conditions as it may see fit to prescribe. . . In the United States this power is vested in the national government, to which the Constitution has committed the entire control of international relations, in peace as well as in war." See Shaughnessy v. United States, 345 U.S. 206 (1953).

108. Fong Yue Ting v. United States, 149 U.S. 698, 707, 711 (1892). See also Hines v. Davidowitz, 312 U.S. 52, 62 (1941). On the major premise as to national power there was no dissent in Fong Yue Ting's case; but on the further question as to constitutional limitations upon the exercise of national power with respect to resident aliens there were vigorous and impressive dissents by Justice Brewer, Justice Field and Chief Justice Fuller. See Lem Moon Sing v. United States, 158 U.S. 538 (1895). Cf. Wong Wing v. United States, 163 U.S. 228 (1896) ; Bridges v. Wixon, 326 U.S. 135 (1945); Kwong Hai Chew v. Colding, 344 U.S. 590 (1953). 


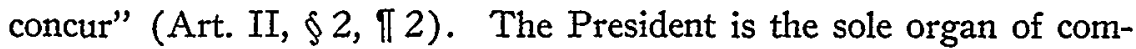
munication with other nations (Art. II, $\$ 2$, $\Uparrow \Uparrow 2$ and 3 ). Corresponding powers are denied the states (Art. I, $\$ 10, \| \Uparrow 1$ and 3 ). The judicial power extends to all cases arising under treaties (Art. III, $\$ 2, \pi 1$ ) and treaties made under "the authority of the United. States" -on a parity with the "Constitution and the laws of the United States which shall be made in pursuance thereof"-are the supreme law of the land (Art. VI, $\$ 2$ ). In the setting reviewed hitherto, there was thus provided a broad and firm foundation for the development of a national law of international agreements. The details of a divided internal authority were irrelevant. Case law would develop in a pattern of impressive consistency.

The first of a long line of notable cases in the Supreme Court was Ware v. Hylton. There was here presented a conflict between Virginia laws of the Revolution providing for the sequestration of debts owed British creditors and the treaty of peace with Great Britain. The case aroused an intense interest and was argued with rather more attention to the Law of Nations than to a constitutional issue. Justice Iredell appears to have struck the keynote in Circuit Court when he remarked: "The subject of treaties, Gentlemen truly say, is to be determined by the law of nations." In the outcome the four justices sitting in Supreme Court concurred in declaring that the treaty must prevail over conflicting state laws. Whatever the competence of Virginia may have been, under the Law of Nations or otherwise, the Constitution had made the treaty the supreme law of the land. ${ }^{109}$

The rationalization of this result was pointed up sharply, years later, in a contest involving alien heirs and local land which was taken up, again from Virginia, on writ of error to the state court. A resident Swiss subject had died intestate leaving Swiss subjects in Switzerland as his next-of-kin. The state proceeded to escheat his Virginia lands; the alien heirs relied upon a treaty with Switzerland which accorded them a right to sell and withdraw the proceeds; and this, said Justice Swayne for the Court in Hauenstein v. Lynham, was "the hinge of the controversy." "The law of nations recognizes the liberty of every government to give to foreigners only such rights, touching immovable property within its territory, as it may see fit to concede," Justice Swayne acknowledged, and in the United States "this authority is primarily in the States where the property is situated." Nevertheless "a treaty stipulation may be effectual to protect the land of an alien

109. 3 Dall. 199 (U.S. 1796). See Crandall, Trearies, Their Making and ENForCEMIENT, 153-160 (2d ed. 1916) ; 1 Warren, op. cit. supra note 9, 144-146. There was no retreat from the underlying doctrine in the years of controversy concerning states' rights. See Attorney General Cushing, in 8 OPS. ATr'Y GEN. 411 (1857). 
from forfeiture by escheat under the laws of a State." The opinion concluded:

"If the national government has not the power to do what is - done by such treaties, it cannot be done at all, for the States are expressly forbidden to 'enter into any treaty, alliance, or confederation.' Const., art. 1 , sect. 10. . . .

"We have no doubt that this treaty is within the treatymaking power conferred by the Constitution. And it is our duty to give it full effect." 110

All this was said again and more eloquently in the following decade in the even more famous case of Geofroy $v$. Riggs. French heirs claimed and were held entitled to share in the inheritance of intestate lands in the District of Columbia. With fine judicial understatement, the opinion noted that the relevant article of the treaty with France was "not happily drawn," and the case is perhaps significant as precedent chiefly for its saving application to the treaty of principles of liberal construction. At the same time Justice Field for the Court summarized an approved understanding of the scope of the treatymaking power in language which was to become classic. He said:

"That the treaty power of the United States extends to all proper subjects of negotiation between our government and the governments of other nations, is clear. It is also clear that the protection which should be afforded to the citizens of one country owning property in another, and the manner in which that property may be transferred, devised or inherited, are fitting subjects for such negotiation and of regulation by mutual stipulations between the two countries. As commercial intercourse increases between different countries the residence of citizens of one country within the territory of the other naturally follows, and the removal of their disability from alienage to hold, transfer and inherit property in such cases tends to promote amicable relations. Such removal has been within the present century the frequent subject of treaty arrangement. The treaty power, as expressed in the Constitution, is in terms unlimited except by those restraints which are found in that instrument against the action of the government or of its departments, and those arising from the nature of the government itself and of that of the States. It would not be contended that it extends so far as to authorize what the Constitution forbids, or a change in the character of the government or in that of one of the States, or a cession of any portion of the territory of the latter, without its consent. . . . But with these exceptions, it is not perceived that there is any limit to the questions which can be adjusted touching any matter which is properly the subject of negotiation with a foreign country." 111 
There was nothing occult in the reasoning upon which these opinions relied. Supplemented by opinions in a considerable miscellany of other cases of lesser note, they need have left no major doubt concerning the judicial attitude toward conflict between an exclusively national and generally comprehensive treaty power, on the one hand, and internal powers reserved to the states, on the other. As often as such a conflict might be permitted to arise, the treaty must prevail. The Supreme Court had indicated its position clearly; and at the turn of the century respected and influential writers were beginning to elaborate with understanding upon the judicial position. ${ }^{112}$

It required another notable case, however, to dramatize the issue and clinch the argument. The case, as no informed professional needs to be reminded, was Missouri $v$. Holland. An attempt to regulate the killing of migratory birds within the states by act of Congress had been adjudged unconstitutional in two district courts. Thereupon a treaty of like objective had been concluded with Great Britain; and the Migratory Bird Treaty Act had been enacted to implement the treaty. ${ }^{113}$ The cause was initiated as a bill in equity by the state to prevent a game warden of the United States from attempting to enforce the implementing act and regulations made thereunder. It was the state's principal contention that what an act of Congress could not do unaided, in derogation of powers reserved to the states, a treaty could not do, and consequently that treaty and statute were void as an invasion of rights reserved by the Tenth Amendment. This argument the Supreme Court rejected in toto, two justices dissenting. Concerning the test for which, the state had contended, Justice Holmes for the majority observed:

"Whether the two cases cited were decided rightly or not they cannot be accepted as a test of the treaty power. Acts of Congress are the supreme law of the land only when made in pursuance of the Constitution, while treaties are declared to be so when made under the authority of the United States. It is open to question whether the authority of the United States means more than the formal acts prescribed to make the convention. We do not mean to imply that there are no qualifications to the treatymaking power; but they must be ascertained in a different way. It is obvious that there may be matters of the sharpest exigency

112. See Butler, The Treaty-Making Power of the United States (1902); and Crandali, op. cit. supra note 109. Cf. Tucker, Limitations on the TreatyMaking Power (1915).

113. The initial attempt in Act of March 4, 1913, 37 STAT. 487, was held unconstitutional in United States v. Shauver, 214 Fed. 154 (1914), and United States v. McCullagh, 221 Fed. 288 (1915). The treaty was proclaimed December 8, 1916, 39 Stat. 1702, and implemented by act entitled as above July 3, 1918, 40 Stat. 755 (1918), as amended 16 U.S.C. \&703 (1946). 
for the national well-being that an act of Congress could not deal with but that a treaty followed by such an act could, and it is not lightly to be assumed that, in matters requiring national action, 'a power which must belong to and somewhere reside in every civilized government' is not to be found." 114

Premises thus firmly established with respect to the scope of the treaty power, the liberal construction of treaties, and their supremacy under the Constitution, have had other and notable applications. ${ }^{115}$ Like premises have guided the courts as they have been called upon to interpret and apply the less formal and somewhat more numerous sorts of international agreements which are concluded by the executive from time to time on its own responsibility or pursuant to an act of Congress. ${ }^{116}$ Judicial consideration of such agreements has not been frequent, but when invoked has indicated indubitably that the less formal sorts have an effect internally which is essentially like that accorded treaties, ${ }^{117}$ not because they are considered "treaties" under another name, but rather because they are a necessary and proper means of conducting external relations. The conduct of foreign relations belongs exclusively to the national government. Over the years the Supreme Court has affirmed many times a conception of nationhood which enables the national government to do generally the "acts and things which Independent States may of right do." In ascertaining what such acts and things may include, an appropriate recourse is to the practice of nations. ${ }^{118}$

114. 252 U.S. 416, 433 (1920). Cf. Attorney General Cushing's summation in the opinion cited supra note 109 , at 415 .

115. Thus these premises have been applied to avoid and supplant a municipal ordinance which would have excluded aliens from the business of pawnbroking, Asakura v. City of Seattle, 265 U.S. 332 (1924); a state inheritance tax which would have discriminated against the non-resident alien heirs of a resident alien decedent, Nielsen v. Johnson, 279 U.S. 47 (1929); and a state succession statute which would have escheated property left locally by a resident alien who had died intestate without known heirs or next-of-kin, Santovincenzo v. Egan, 284 U.S. 30 (1931).

116. See McClure, International Executive Agreenents (1941); Levitan, Executive Agreenents: $A$ Study of the Executive in the Control of Foreign Relations, 35 Int. L. Rev. 365 (1940); Moore, Treaties and Executive Agreements, 20 PoL. ScT. Q. 385 (1905).

117. See United States v. Belmont, 301 U.S. 324 (1937); United States v. Pink, 315 U.S. 203 (1942).

118. In United States v. Curtiss-Wright Export Corp., 299 U.S. 304 (1936) Justice Sutherland said (at 318): "As a member of the family of nations, the right and power of the United States in that field are equal to the right and power of the other members of the international family. Otherwise, the United States is not completely sovereign. The power to acquire territory by discovery and occupation (Jones v. United States, 137 U.S. 202, 212), the power to expel undesirable aliens (Fong Yue Ting v. United States, 149 U.S. 698, 705 et seq.), the power to make such international agreements as do not constitute treaties in the constitutional sense (Altman \& Co. v. United States, 224 U.S. 583, 600-601; Crandall, Treaties, Their Making and Enforcement, 102 and note 1); none of which is expressly affirmed by the Constitution, nevertheless exist as inherently inseparable from the conception of nationality. This the court recognized, and in each of the cases cited found the war- 
A sampling of the case law of external relations may be carried no further, within the limits of this paper, tempting as other directions may be. There is much case reporting on matters of sovereign immunity, for example, wherein the judicial consciousness of a patterned reliance upon international usage and agreement is impressively consistent. There is a profusion of reporting on matters of war and traditional neutrality in which the same patterned reliance is strikingly revealed. There are other areas rich in illustration; and there is of course the whole. A treatise could have done the job better than part of an essay, needless to confess, though hope persists that the part here concluded may contribute something to understanding of the whole. The generalities and necessary implications of an undistributed nationai power over relations with other nations have required a vast deal of implementing. Legislation has contributed much; treaties have contributed more; and judicial administration over the years has combined meaningful applications in a multitude of instances with much illuminating rationalization. In each aspect of its enterprise, judicial administration has been fortified by the Law of Nations, firmly established from the beginning as a part of the national law.

\section{V.}

There is no evident need for an extended summary of this study. Indeed, the study itself has been something of an attempt at summarizing. In the earlier paper, beginning with a brief account of Anglo-American legal tradition with respect to the Law of Nations in the eighteenth century, we traced and in some measure endeavored to appraise the tradition's influence upon the making of a national constitution and the legislative implementing of national judicial power. In the present paper, we have been concerned with the progress of the Law of Nations in American judicial administration. The principal parts of the narrative are fairly well known, at least to specialists in the principal parts, though it is doubted that they can be fully understood by anyone out of context or apart from the whole. Accordingly we have endeavored to place each in relation to the whole in the overall summation of a single narrative.

Individual offences against the Law of Nations, within reach of federal courts administering a federal common law of crimes, became

rant for its conclusions not in the provisions of the Constitution, but in the law of nations."

Current proposals for a return to confederation by way of constitutional amendment restricting the power to enter into treaties and agreements are beyond the scope of this study. See Perlman, On Amending the Treaty Power, 52 CoL. L. REV. 825 (1952); Sutherland, Restricting the Treaty Power, 65 HARv. L. REv. 1305 (1952). 
a casualty of early political controversy. Today, with resulting unsettlements and inconveniences long since repaired by national penal legislation, there will perhaps be few if any to bemoan their passing. The law merchant of the Law of Nations flourished hopefully in the earlier years, but most of it died later in the controversies precipitated by some extraordinary judicial overreaching. One may perhaps wonder today whether its premises of universality were ever quite suited to the conditions which were to develop within the United States. The law maritime of the Law of Nations, on the other hand, has developed substantially in the course envisaged and charted by the founding fathers. There were factors contributing before the event, as we have endeavored to suggest, but doubtless as important as these was the demonstrated viability of the ancient system in response to the changing needs of both foreign and domestic waterborne commerce in the western world. The law of states has likewise grown steadily in utility and importance as a prime resource of national law with respect to most matters of international concern. Though the present scope and content of this phase or branch of our national law could hardly have been foreseen by the most prescient of the framers, the course to be followed was charted consciously and wisely. It has been as steadily pursued, and of necessity, one is tempted to say, if the United States is to maintain its place as "a part of the civilized world." 